\title{
Jan Mayen
}

National Cancer Institute

\section{Source}

National Cancer Institute. Jan Mayen. NCI Thesaurus. Code C123760.

An island in Northern Europe, between the Greenland Sea and the Norwegian Sea. 